\title{
Hoofstuk 4
}

\section{Die geskiedenis van die oorgelewerde teks}

Hoewel alle bekende bronne van die teks van die Nuwe Testament aan teksvariasie onderworpe was en daar dus foute en veranderinge in alle bronne voorkom, het die noukeurige bestudering van die bronne getoon dat nie almal in dieselfde mate daaraan blootgestel was nie en dat die bronne van mekaar verskil ten opsigte van die aard, inhoud en omvang van die teksvariasie daarin. Gevolglik is bepaalde tendense in die bronne geïdentifiseer, waarvolgens hulle gekarakteriseer kan word. In die meeste gevalle is hierdie tendense nie tot indiwiduele bronne beperk nie, maar vertoon 'n groep bronne (veral dié wat op dieselfde plek en in min of meer dieselfde tyd ontstaan het) min of meer dieselfde karaktertrekke. Op hierdie wyse is die bronne van die teks van die Nuwe Testament dus aan mekaar verwant en kan hulle op grond van die kenmerkende lesings van elk in groter en kleiner groepe, wat gemeenskaplike kenmerke openbaar, verdeel word. Deur die kenmerkende eienskappe van die verskillende groepe te bestudeer, kan weer bepaal word hoe die groepe aan mekaar verwant is en hoe en waarom die bepaalde kenmerke van elke groep ontstaan het. Hierdie is alles elemente wat met die geskiedenis van die teks te make het. Dit gaan dus om die beskrywing van die wyses waarop, die plekke waar en die vorme waarin die teks oorgelewer is. Die uiteindelike doel daarvan is om so noukeurig moontlik te bepaal in watter manuskripte en ander bronne die teks van die oorspronklike weergawe van die boeke van die Nuwe Testament die akkuraatste oorgelewer is.

Omdat daar geen historiese beskrywings van enige aspek van die oorlewering van die teks bestaan nie, moet die geskiedenis van die teks uit die bronne self gerekonstrueer word. Dit behels 'n noukeurige bestudering van al die bronne van die teks van die Nuwe Testament. Hierdie is 'n pynlike proses wat baie noukeurige studie vereis. Die gerekonstrueerde geskiedenis wat hieronder aangebied word, is daarom nie die werk van een of twee indiwidue nie, maar die gevolg van letterlik eeue se ondersoek en navorsing (soos uit die volgende hoofstuk sal blyk), waarin resultate telkens in die lig van nuwe getuienis van bronne wat deur opgrawings na vore gekom het, bevraagteken, bevestig, verander of verwerp is.

Litcratuur: Epp 1974; Klijn 1960/61.

\section{DIE OMSTANDIGHEDE WAARONDER DIE TEKS OORGELEWER IS}

Voordat die geskiedenis van die teks self beskryf word, is dit interessant om kortliks 
te kyk hoe die wêreld waarin die teks oorgelewer is, gelyk het. So kan 'n opname gemaak word van die omstandighede wat die oorlewering van die teks kon beïnvloed. Veral vier aspekte is belangrik, naamlik die paleografie, die wêreldgeskiedenis, die kerkgeskiedenis en die kanongeskiedenis. Omdat breedvoerig in die eerste hoofstuk aan die paleografie en die invloed daarvan op die teks en die variasie in die teks aandag gegee is, word dit nie weer hier bespreek nie.

\subsection{Die kanongeskiedenis}

Sover vasgestel kan word is al 27 boeke van die Nuwe Testament oorspronklik in Grieks geskryf. Elk van die boeke is indiwidueel op verskillende plekke in verskillende tye geskryf en is aan verskillende mense op verskillende plekke geadresseer. Indien die vroeë daterings van die boeke aanvaar word, beteken dit dat die eerste boek in ongeveer $50 \mathrm{n} \mathrm{C}$ geskryf is en die laaste in ongeveer $95 \mathrm{n} \mathrm{C}$. Die ontstaan van die Nuwe Testament strek dus oor byna 'n halwe eeu, wat beteken dat die eerste boeke al vir byna vyftig jaar oorgelewer is voordat die laastes geskryf is.

Gedurende hierdie heel vroeë tydperk van oorlewering (die 1ste eeu) was daar waarskynlik ook talle ander boeke oor dieselfde onderwerpe in omloop, sowel as 'n baie sterk mondelinge tradisie. Dit het uiteraard die oorlewering van die boeke in die Nuwe Testament beïnvloed, sodat daar 'n vroeë proses van redaksionele arbeid aan die boeke was, voordat dit die vorm waarin dit vandag bekend is, aangeneem het. Hierdie oor-en-weer beïnvloeding tussen geskrewe en mondelinge tradisies bring mee dat die vroeë literêre geskiedenis en teksgeskiedenis van die boeke vermeng is en dat baie van die variasie in veral die historiese boeke hulle oorsprong gehad het in die tydperk voordat die boeke hulle finale beslag gekry het. Elke boek het vir 'n lang tyd gevolglik 'n eie oorleweringsgeskiedenis gehad. Tog is dit uit verskillende aspekte van die geskiedenis duidelik dat die boeke van die Nuwe Testament betreklik gou die vorm waarin hulle vandag bekend is, aangeneem het, sodat daar moontlik reeds teen die einde van die 1ste eeu van 'n textus receptus van die boeke wat vandag in die Nuwe Testament staan (hoewel nie van die Nuwe Testament as geheel nie), gepraat kan word. Na die ontstaan van so 'n textus receptus is die variasie waarskynlik bekamp en al hoe meer en meer beperk tot werklike teksvariasie eerder as redaksionele variasie (as daar inderdaad 'n verskil tussen die twee is). Wat egter hieruit belangrik is vir die teksgeskiedenis, is die feit dat elke boek waarskynlik in die 1ste eeu 'n eie (teks- en literêre) geskiedenis het wat in ag geneem moet word wanneer die geskiedenis van die oorlewering van die Nuwe Testament in geheel gerekonstrueer word.

'n Tweede aspek van die kanongeskiedenis wat 'n invloed op die 
teksgeskiedenis gehad het, is die geskiedenis van die erkenning en aanvaarding van die boeke as gesagvolle religieuse dokumente. Die proses van die bundeling van die boeke het vroeg begin en reeds vroeg in die 2 de eeu of selfs in die 1ste eeu is daar tekens dat byvoorbeeld 'n aantal briewe saam as 'n Pauliniese Korpus oorgelewer is. Die probleme rondom die erkenning en aanvaarding van die boeke as deel van die kanon vir die volgende drie of vier eeue het die teksgeskiedenis ewe-eens beïnvloed, omdat sommige boeke op sommige plekke as deel van die kanon en op ander plekke as buite-kanoniese geskrifte oorgelewer is. Vir ' $n$ tyd lank is die boeke dus sowel indiwidueel as in bundels oorgelewer, voordat die Nuwe Testament sy finale beslag in die 4de eeu gekry het. Die indiwidualiteit in die geskiedenis van die boeke in die 1ste eeu het dus in ' $n$ mindere of meerdere mate voortgeduur, afhangende van die betrokke boek se posisie in die kanon in die 2 de tot 4 de eeu. Hierdie aspekte van die kanongeskiedenis word bevestig deur byvoorbeeld die oorlewering van Openbaringboek, wat geheel anders verloop het as die oorlewering van die meeste ander boeke in die Nuwe Testament, waarskynlik omdat die kanonisiteit van hierdie boek vir so 'n lang tyd betwis was.

Van groot belang vir die oorlewering van die Nuwe Testament is twee kerkvaders uit die 2de eeu, wat nou by die kanongeskiedenis betrokke is.

Die eerste is Tatianus, die Siriese kerkvader wat die harmonie van die Evangelies, die Diatessaron, daargestel het. Die presiese invloed van die Diatessaron op die oorlewering van die vier Evangelies kan moeilik bepaal word, maar daar word aanvaar dat talle gevalle van harmoniëring in die manuskripte van die Evangelies hul oorsprong by Tatianus se Diatessaron het.

'n Besonder belangrike figuur in die 2de eeu was Marcion. Wat hom vir die geskiedenis van die teks belangrik maak, is die feit dat hy direk by die kanon en teks betrokke geraak het, deurdat hy sy kanon beperk het tot tien van die Pauliniese briewe en 'n hersiene weergawe van die Derde Evangelie, waarin sommige dele weggelaat en ander dele verander is. Verder het sy groot invloed in die vroeë kerk meegebring dat baie van veral die veranderinge in die Lukasevangelie waarskynlik hul weg tot in die manuskripte van die ortodokse oorleweringstradisie gevind het.

Literatuur. K Aland 1967e; $1967 f$.

\subsection{Die kerkgeskiedenis}

Die kerklike omstandighede waaronder die teks in die eerste aantal eeue oorgelewer is, het waarskynlik 'n groot rol in die geskiedenis van die teks gespeel. Die gemeentes was oor die algemeen kleiner as vandag. In baie gevalle was die 
gemeentes so klein dat eredienste, veral in die 1ste eeu, in huise gehou kon word dus iets soortgelyk aan die moderne Bybelstudiegroep. Baie van die vroeë gemeentelede was arm en ongeletterd, of dan ten minste swak geletterd. Dit het meegebring dat die oorlewering van die teks aanvanklik waarskynlik spontaan plaasgevind het en aan geen amptelike standaard moes voldoen nie. Voeg hierby die geweldige vervolginge waaronder die Christene in die eerste drie eeue gebuk gegaan het en dit word nog duideliker waarom daar so baie variasie in die manuskripte voorkom. Kopieerwerk moes dikwels haastig in 'n gespanne atmosfeer, by swak lig in katakombes en deur mense wat vir hulle lewens gevrees het, gedoen word. Tyd om die manuskrip te kontroleer, was daar nie en in baie gevalle was die blote besit van 'n teks al 'n luuksheid, wat detail soos die kontrolering van variasie totaal oorbodig gemaak het. Hierdie omstandighede maak dit duidelik dat die meeste van die foute in die manuskripte waarskynlik uit hierdie tydperk dateer, en dat van die belangrikste variasie waarskynlik reeds in die eerste aantal kopieë van die boeke kon voorgekom het.

Namate die kerk egter begin groei het (in getalle, geletterdheid en rykdom) en die vervolging begin afneem het, kan aanvaar word dat die spontaniteit in die oorleweringsproses begin afneem het en dat die oorlewering 'n al hoe groter amptelike karakter begin kry het. Veral die verandering in die posisie van die kerk na die bewindsoorname van Konstantyn, vroeg in die $4 \mathrm{de}$ eeu, het hierdie proses waarskynlik verhaas, deurdat dit die ruimte daarvoor geskep het dat die teks amptelik in skriptoria oorgelewer kon word.

Hierdie verandering het verskillende implikasies vir die teksgeskiedenis gehad: Die oorleweringsproses is bespoedig deurdat professionele skriptors hulle voltyds daarmee kon besig hou. Die gebruik van opgeleide skriptors en korrektors in skriptoria het meegebring dat waarskynlik minder foute in die oorleweringsproses gemaak is. Die verandering in die posisie van die kerk sedert Konstantyn het ook die proses van standaardisering bevorder. Dit is nie toevallig dat sowel die Vulgata as die Peshitta as standaarduitgawes van die Latynse en Siriese vertalings juis na die wending in die kerkgeskiedenis, wat deur Konstantyn meegebring is, verskyn het nie. Ook die Griekse teks het in hierdie tyd die een of ander proses van standaardisering deurgegaan, wat uiteindelik in die teks van die Middeleeue gereflekteer is.

Ten slotte het ook die ontwikkeling van die teologie, teologiese debatte en teologiese verskille waarskynlik 'n al hoe groter invloed op die oorlewering van die teks begin uitoefen, en daar is vandag spore van teksverandering in die manuskripte wat aan sowel die heterodokse as ortodokse leer toegeskryf kan word.

Literatuur: Aland \& Aland 1982; Bartsch 1983; Fee 1978/79; Pickering 1980; Van Bruggen 1976. 


\subsection{Wêreldgeskiedenis}

Uit die wêreldgeskiedenis het veral twee sake 'n pertinente invloed op die oorlewering van die teks van die Nuwe Testament gehad, naamlik die wêreldtaal en die sentra van geleerdheid.

Waar Grieks in die eerste twee of drie eeue vanweë die invloed van die Hellenisme 'n wêreldtaal was en algemeen bekend was en gebruik is, het die moedertale Grieks algaande vervang. Dit het daartoe gelei dat in die 2de en 3de eeue begin is om die Nuwe Testament te vertaal, wat weer die gebruik van die Griekse teks in sekere gebiede algaande beperk het.

Dit het uiteraard ook die oorlewering van die Griekse teks in daardie gebiede beperk, omdat die behoefte aan Griekse Bybels deur 'n behoefte aan vertaalde Bybels vervang is. Veral die gebruik van die Latynse Bybel (Vulgata) in die Weste het hierdie proses bespoedig, deurdat die Griekse teks sedert ongeveer die 4de of 5 de eeu in die Weste verdring is.

Ten slotte het ook die sentra van geleerdheid in die destydse wêreld 'n belangrike invloed op die oorlewering van die teks gehad. Alexandrië, die bekende stad in Noord-Afrika wat na Alexander die Grote vernoem is, was byvoorbeeld bekend vir sy biblioteek waarin 'n geweldige versameling antieke tekste bewaar is. Nie alleen was hierdie sentrum bekend vir uiters noukeurige kopiëring van manuskripte nie, maar dit was ook bekend dat manuskripte hier soms stilisties bewerk is. Dit kan dus verwag word dat die manuskripte wat aan hierdie gebied gekoppel kan word, noukeurige en akkurate verteenwoordigers van die manuskripte waarvan hulle gekopieer is, sou wees, terwyl hulle tog moontlik taalkundige verbetering kon ondergaan het.

\section{OORSIG OOR DIE TEKSGESKIEDENIS}

Die oorlewering van die Nuwe Testament het 'n lang en komplekse geskiedenis. Vanweë die aard van die bronne waaruit dit gerekonstrueer moet word, is daar oor vele aspekte daarvan meningsverskil en onduidelikheid. Voordat in die detail daarvan verval word, is dit nodig om 'n breë oorsig daaroor te gee, ten einde 'n verwysingsraamwerk vir die bespreking van indiwiduele aspekte daarvan te bied.

Die eerste tydperk wat onderskei word, is die vroeë tydperk en strek ongeveer tot in die middel van die 2 de eeu. Dit is ' $n$ tydperk waaroor min bekend is, omdat daar geen direkte bronne uit hierdie tydperk bestaan nie. Dit blyk egter dat die teks in drie vorme oorgelewer is, naamlik 'n getroue vorm, 'n vorm waarin bepaalde gekontroleerde foute voorgekom het en 'n wilde of ongekontroleerde vorm. 
Die tweede tydperk (middel van die 2 de tot 4 de of 5 de eeu) staan as die tydperk van die teksfamilies bekend. Uit die tradisies van die vroeë periode het drie tekstipes of teksfamilies in die 2de en 3de eeu ontwikkel, 'n Alexandrynse teks, wat in Alexandrië sentreer en waarin die teks baie noukeurig oorgelewer is; 'n Westerse teks, wat gekenmerk word deur baie twyfelagtige lesings en wat waarskynlik die produk van die wilde oorleweringstradisie van die vroeë periode was; en 'n Caesareaanse teks, wat aanvanklik 'n tekstuele proses tussen die Alexandrynse en Westerse tekste was en later moontlik in 'n eie tekstipe oorgegaan het. Dit verteenwoordig moontlik'n baie vroeë spontane poging tot standaardisering.

Die derde tydperk (die 4 de en 5 de eeu) staan as die tydperk van standaardisering bekend. In hierdie tydperk kom die Bisantynse standaardteks, 'n eklektiese teks uit die vroeëre tekstipes, wat die oorlewering van die teks in die Middeleeue sou domineer, tot stand. Die Alexandrynse teks ondergaan gedurende hierdie tydperk ook redaksionele arbeid, sodat die verteenwoordigende bronne van die Alexandrynse teks al hoe meer invloede van die Westerse en Bisantynse tekste vertoon. Om hierdie Alexandrynse teks van die vroeë Alexandrynse teks te onderskei, word van die Egiptiese teks gepraat. Die proses wat in die Caesareaanse teks begin is, bereik sy voltooiing in hierdie tydperk, sodat die Caesareaanse teks as selfstandige tekstipe geïdentifiseer kan word. Ten slotte is daar tekens dat ook die redaksionele arbeid aan die Westerse teks 'n hoogtepunt in die teks van Kodeks D bereik.

Die 5de tot 9de eeue staan as die tydperk van die vroeë standaardteks bekend. Dit is 'n tydperk waarin die gestandaardiseerde Bisantynse teks sy finale beslag gekry het en 'n al hoe groter uniformiteit onder sy bronne begin ontwikkel het. Die ander tekstipes het gedurende hierdie tydperk finaal tot 'n einde gekom, sodat hulle teen die middel van die Middeleeue vir alle praktiese doeleindes nie meer bestaan het nie.

Gedurende die 9 de tot $16 \mathrm{de}$ eeue, die tydperk van die Middeleeuse minuskelteks, domineer die Bisantynse teks die teksgeskiedenis in so 'n mate dat verreweg die meeste minuskels en leksionaria aan hierdie tekstipe behoort. Die proses van standaardisering is nie alleen voltooi nie, maar bereik in hierdie tydperk ook sy volle wasdom. Op verrassende wyse kom daar egter gedurende hierdie tydperk ook enkele manuskripte voor met tekste wat aan vroeëre tekstipes behoort.

Ofskoon enkele manuskripte nog na die 16de eeu gedateer word, eindig die geskiedenis van die oorgelewerde teks vir alle praktiese doeleindes in die 16de eeu, omdat die eerste gedrukte teks vroeg in die 16de eeu van die drukpers gekom het.

Literatuur: K Aland 1981; Aland \& Aland 1982; Birdsall 1970; Duplacy 1966; Greenlee 1964; Junack 
1978; Kenyon 1912; Metzger 1966; 1968b; 1971; Streeter 1924; Vaganey 1937; Von Soden 1902-1910; Westcott \& Hort 1974.

\section{DIE VROEë PERIODE (1STE TOT VROEë 2DE EEU)}

Oor die eerste ongeveer anderhalfeeu waartydens die teks van die Griekse Nuwe Testament oorgelewer is, is weinig bekend, omdat daar geen direkte bronne daaroor is nie. Die vroegste manuskripte en vertalings dateer eers uit die $2 \mathrm{de}$ eeu, met die gevolg dat vaste grond in die oorlewering van die teks eers in hierdie tydperk betree kan word. Wat in hierdie vroegste tydperk gebeur het, moet dus afgelei word uit dit wat uit die bronne van die 2 de eeu en later bekend geword het.

Uit die vroegste manuskripte van die Griekse Nuwe Testament blyk dit dat hierdie eerste eeu of eeu-en-'n-half gekenmerk is deur 'n ongekontroleerde oorlewering van die teks. Daarmee word bedoel dat daar weinig of geen amptelike kontrole oor die noukeurigheid van die kopieerwerk was nie. Benewens die feit dat die praktiese omstandighede in die kerk kontrolering moeilik gemaak het, het die mense in hierdie tydperk waarskynlik meer in die inhoud as die presiese bewoording van die teks belang gestel. Daarby was daar'n sterk mondelinge tradisie wat min of meer dieselfde aspekte as veral die Evangelies gedek het, wat op sy beurt weer meegebring het dat daar 'n mate van oor-en-weer-beïnvloeding plaasgevind het. Lesings is uit die mondelinge tradisie in die Evangelies ingedra, terwyl ander lesings wat vreemd op die oor geval het, soms weggelaat is, sonder dat die akkuraatheid daarvan op enige wyse gekontroleer is. Op hierdie wyse het waarskynlik die meeste van die variante lesings in manuskripte wat vandag bekend is, in hierdie tydperk ontstaan.

Omdat daar geen direkte bronne uit hierdie tydperk beskikbaar is nie, is dit nie moontlik om te bepaal of die teks op bepaalde plekke meer getrou as op ander plekke oorgelewer is nie. Wanneer die oudste manuskripte egter ontleed word en wanneer in ag geneem word dat hulle van archetipes gekopieer is wat uit hierdie tydperk kom, is dit tog moontlik om veral drie breë tradisies onder die manuskripte van hierdie tydperk te identifiseer. Hierdie tradisies word nie van mekaar onderskei omdat hulle met bepaalde plekke geïdentifiseer kan word nie, maar word bloot geïdentifiseer op grond van die kwaliteit en akkuraatheid van die manuskripte waarin hulle voorkom. Aan die een kant was daar 'n tradisie waarin die teks baie getrou oorgelewer is en wat aan weinig tekskorrupsie blootgestel was. Van die vroegste papiri, soos $\mathrm{P}^{75}$, is hiervan waarskynlik 'n bewys. Naas hierdie tradisie was daar ' $n$ tradisie waarin die teks oorgelewer is met 'n bepaalde soort variante lesing, wat die teks tot in die laaste stadia van oorlewering gekenmerk het. Hierdie tradisie 
het dus 'n teks gehad wat minder akkuraat as die eerste oorgelewer is, maar wat tog op die een of ander wyse gekontroleer is. $\mathrm{P}^{72}$ is waarskynlik hiervan ' $\mathrm{n}$ voorbeeld. Ten slotte is daar tekens van 'n soort wilde of vrye tradisie. Dit is manuskripte wat talle eiesoortige lesings bevat, wat waarskynlik die gevolg van onnoukeurige skriptors was. $\mathrm{P}^{66}$ getuig hiervan. Hierdie drie tradisies vorm die basis vir die oorlewering van die teks in die volgende eeue.

Hoewel hierdie teorie in 'n sekere mate gangbaar is, is dit vanweë die gebrek aan vaste getuienis onmoontlik om dit met oortuiging te bewys.

Literatuur: K Aland 1981; Aland \& Aland 1982; Fee 1964; 1968; 1974b; Kilpatrick 1976.

\section{DIE TEKSFAMILIES (MIDDEL 2DE TOT 4DE EEU)}

Vaster grond word teen die einde van die 2 de en vroeg in die 3de eeu betree, deurdat hierdie tydperk aan die hand van eietydse manuskripte beoordeel kan word. Dit is egter steeds noodsaaklik om versigtig te wees by die maak van gevolgtrekkings, en om eerder beskeie as te oortuigende gevolgtrekkings te maak, omdat met enkele uitsonderings al die bronne vir die rekonstruksie van die geskiedenis van hierdie tydperk uit dieselfde gebied, Egipte of die Midde-Ooste, afkomstig is. Dit kan dus nie met vaste sekerheid bewys word of hierdie bronne verteenwoordigend van die teks in die algemeen, of slegs verteenwoordigend van die teks in Egipte is nie. Nieteenstaande hierdie probleem, is dit tog moontlik om 'n algemene prentjie van die teksgeskiedenis van hierdie tydperk met meer oortuiging as die vroeë tydperk te konstrueer.

Gedurende die 2 de eeu het die aard van die oorlewering verander, deurdat bepaalde tekstipes en bepaalde teksfamilies in bepaalde gebiede ontstaan het. Teksfamilies is groepe manuskripte wat dieselfde karakteristieke lesings bevat en tekstipes is die versameling lesings wat so 'n teksfamilie karakteriseer. Die ontstaan van teksfamilies in hierdie tydperk is waarskynlik aan twee faktore toe te skryf. In die eerste plek het daar waarskynlik groter kontrole oor die oorlewering van die teks gekom. Daar is begin om manuskripte in bepaalde gebiede met mekaar te vergelyk ten einde verskille uit te skakel en die teks in die gebiede te standaardiseer. 'n Belangrike faktor is egter, in die 2de plek, die ontstaan van die vertalings in hierdie tydperk. Die aanvang van die vertaling van die teks het uiteraard daartoe gelei dat besluit moes word watter manuskripte vir die vertaling gebruik moes word. Dit het uiteraard besinning oor die teks meegebring en 'n groter kritiese bewussyn help ontwikkel. Ook het die bestaan van die vertaling meegebring dat 'n tipe standaard bestaan het wat bepaalde lesings in die betrokke gebied geyk het. Manuskripte van 
die Griekse teks is gevolglik spontaan in die betrokke gebied aan die hand van die vertalingstekste gekontroleer. So het daar in die loop van die laaste deel van die 2de eeu en die 3de eeu dus tekstipes in bepaalde geografiese gebiede ontwikkel. Hierdie tekstipes word vandag lokale tekste of lokale tekstipes genoem. Die aanvanklike ontwikkeling was waarskynlik spontaan en eers later het definitiewe hersieningswerk voorgekom in 'n poging om die tekstipes formeel te standaardiseer.

Literatuur: K Aland 1965; 1967a; Birdsall 1957a; Colwell 1952; 1957/58; 1969; Epp 1974; Junack 1978; Reicke 1966; Schäfer 1960; Thiele 1967.

\subsection{Die Alexandrynse teks}

Die vroegste twee tradisies wat op hierdie wyse ontstaan het, is die Alexandrynse en Westerse tekste. Die Alexandrynse teks (soms ook genoem die Proto-Alexandrynse, Vroeë Alexandrynse of Neutrale teks) word, soos die naam daarvan aandui, met Alexandrië en die tekskritiese praktyke van hierdie stad verbind. Die bronne van hierdie tekstipe was die getroue en noukeurige tradisie van die vroeë periode. Dit is gevolglik 'n tekstipe waarin die teks getrou oorgelewer is, waarskynlik vanweë die noukeurigheid in die versorging en hantering van tekste deur die wetenskaplike tradisie in Alexandrië. Laat in die 3de en vroeg in die 4de eeu is daar spore van'n spontane hersiening te bespeur. Dit het hoofsaaklik op taalkundige en stilistiese variasie betrekking gehad.

Die enigste vertaling waarin hierdie tekstipe voorkom, is die Sahidiese vertaling, terwyl kenmerkende lesings daarvan af en toe ook in sekere dele van die oud-Siriese vertalings (Curetoniaans- en Sinaïties-Siries) voorkom. Die belangrikste ander bronne van hierdie teks is $\mathrm{P}^{75}$ en Kodeks Vaticanus (B), wat, hoewel dit 'n 4 de-eeuse manuskrip is, baie nou met $\mathrm{P}^{75}$ ooreenkom en waarskynlik op 'n vroeë archetipe teruggaan. Hierby kom ook Kodeks $\boldsymbol{K}$, wat egter soms 'n aantal Westerse lesings bevat en in Jh 1:1-8: 38 selfs 'n Westerse teks bevat. Onder die kerkvaders haal veral Clemens van Alexandrië en Origenes uit hierdie tekstipe aan.

Die Alexandrynse tekstipe word vandag as die belangrikste tekstipe beskou en die manuskripte, die vertalings daarvan en kerkvaders wat daaruit aanhaal, tel onder die belangrikste bronne vir die herstel van die teks. Die teks kan gekarakteriseer word as 'n kort teks, wat beteken dat talle lang en korter interpolasies wat in ander tekstipes voorkom, nie in hierdie tekstipe gevind word nie. 'n Tweede kenmerk is dat dit soms taalkundige en stilistiese verbeterings bevat. Daar is egter weinig spore van sistematiese hersienings- of redaksionele arbeid in die getuienisse van hierdie teks te vind. 
Literatuur: Aland \& Aland 1982; Birdsall 1960; AC Clark 1914; KW Clark 1962; Colwell 1969i; EG Edwards 1977; Ehrman 1986; JK Elliott 1974; Fee 1971b; 1974a; 1974b; 1982b; Finegan 1974; Globe 1980; Hills 1950; Hodges 1962; King 1964; Klijn 1956/57; 1971; Kubo 1965; Martini 1978; Metzger 1966/67a; 1968b; 1971; Porter 1962; 1967; Souter 1960; Vaganey 1937; Westcott \& Hort 1974; Zuntz 1953.

\subsection{Die Westerse teks}

Die Westerse teks is waarskynlik net so oud soos die Alexandrynse teks. Oor hierdie teks bestaan daar egter meer onduidelikhede as helderheid. Dit is byvoorbeeld onseker presies waar en hoe hierdie teks, wat waarskynlik die mees algemene teks laat in die 2 de en vroeg in die 3 de eeu was, ontstaan het. Die bronne vir hierdie teks kom ook in die vroeë periode voor, en dit blyk dat die Westerse teks veral uit aspekte van die wilde vorm (die derde een in die vroeë periode), maar met behoud van sekere elemente van die ander twee tradisies, ontwikkel het. Die naam van die teks dui aan dat dit êrens in die Weste ontwikkel het. Die rede daarvoor is dat die bronne van hierdie teks vir 'n baie lang tyd uit die 5de-eeuse manuskrip D, die Vetus Latina en die oud-Siriese manuskripte bestaan het. Dit het selfs daartoe gelei dat sommiges eerder van 'n Latynse tekstipe wou praat en dat in ekstreme gevalle gemeen is dat hierdie tekstipe sy ontstaan by die Latynse vertalings gehad het. Dat hierdie tekstipe egter nie by die Latynse vertaling ontstaan het nie, dat dit nie tot die Weste beperk was nie en dat dit selfs moontlik nie eers in die Weste ontstaan het nie, is bewys deur die ontdekking van Griekse manuskripte soos $\mathrm{P}^{29}, \mathrm{P}^{38}$ en $\mathrm{P}^{48}$. Hierdie manuskripte het aangetoon dat die teksvorm moontlik in Egipte ontstaan het. Die feit dat die oud-Siriese vertalings ook 'n Westerse teks bevat (hoewel dit soms ook Alexandrynse lesings bevat) blyk hierdie teorie te ondersteun. In elk geval ondersteun dit die teorie dat die Westerse teks na alle waarskynlikheid die mees bekende teksvorm in die 2de en 3de eeu was, aangesien daar in hierdie manuskripte bewyse is dat dit in Egipte, Sirië, Noord-Afrika, Italië, Spanje en die Weste in die algemeen bekend was. Hierdie laaste teorie oor die ontstaan van die Westerse teks het daartoe gelei dat in sommige kringe nie meer na hierdie teks as 'n Westerse teks verwys word nie, maar dat eerder na die D-teks verwys word, omdat dit in Kodeks D voorkom.

Uit die Latynse bronne van hierdie teks is dit duidelik dat daar 'n aantal subtekstipes binne hom bestaan het. Die bekendste en belangrikste is die sogenaamde $A$ fra, 'n teksvorm wat laat in die 2 de eeu moontlik in Kartago ontwikkel is, en wat die vroegste bekende vertaling van die Nuwe Testament in Latyn verteenwoordig. Daarteenoor staan die Itala, die Europese weergawe van die 
Latynse vertaling, wat 'n latere Latynse teks verteenwoordig en waarin spore van redaksionele hersiening gevind kan word. Presies wat die verhouding van die Griekse, Koptiese en Siriese verteenwoordigers van hierdie tekstipe tot hierdie twee subtekstipes in die oud-Latynse vertaling is, is nog nie met sekerheid vasgestel nie, ofskoon dit bekend is dat Kodeks $\mathrm{D}$ waarskynlik aan die Itala-tekste verwant is.

Die belangrikste eienskappe van die Westerse tekstipe is dat dit in vergelyking met ander tekstipes ' $n$ lang teks is. Dit bevat naamlik 'n aantal treffende interpolasies wat nie in ander tekstipes voorkom nie. Dit geld veral die laaste hoofstukke van Lukas en Handelinge in geheel. In totaal is die Westerse teks van Handelinge byvoorbeeld ongeveer tien persent (ongeveer honderd verse!) langer as die Alexandrynse teks van dieselfde boek. Wat die bron van hierdie interpolasies is, is nog nie bevredigend opgeklaar nie.

'n Tweede belangrike kenmerk van die Westerse teks is dat, in teenstelling met die neiging tot interpolasie, daar soms egter ook treffende weglatings in voorkom. Dit is weer veral 'n kenmerk van die laaste hoofstukke van die Lukasevangelie. Hierdie eienskappe van die tekstipe het daartoe gelei dat sommige sy oorsprong by Marcion se hersiening van die Derde Evangelie gesoek het. Verder word die Westerse teks gekenmerk deur 'n geneigdheid tot harmoniëring en 'n poging om die teks inhoudelik en grammatikaal af te rond en te voltooi deur die byvoeging van kort frases of woorde, wat die betekenis van die teks beter na vore moet bring.

'n Vierde eienskap van die teks is sy neiging tot parafrase, waarvolgens nie deeglike aandag aan sake soos woordorde gegee is nie. Ten slotte word die teks gekenmerk deur doelbewuste inhoudelike veranderinge, waarvan 'n groot element in veral Kodeks D 'n sterk anti-Judaïstiese tendens bevat het.

Omdat hierdie tekstipe hoofsaaklik in die Weste, waar Latyn spoedig die dominerende kerktaal geword het, oorgelewer is, bestaan daar baie min Griekse manuskripte wat die Westerse tekstipe bevat.

Literatuur: B Aland 1976; 1986a; Aland \& Aland 1982; Birdsall 1970; M Black 1981; Boismard 1981; Boismard \& Lamouille 1987; Boismard \& Lamouille (eds) 1984; AC Clark 1918; 1970; Colwell 1969;; Epp 1962; 1966a; 1966b; Hanson 1965/66; Kenyon 1012; Kilpatrick 1943; 1944b; 1980; Klijn 1959a; 1959b; 1966; 1969; 1971; Lindbars 1957/58; Mees 1969; Metzger 1966; 1968b; 1971; Pack 1960d; Reicke 1966; Rice 1980a; 1980b; Schäfer 1960; Snodgrass 1972; Thiele 1965b; Vaganey 1937; Westcott \& Hort 1974; Zuntz 1953. 


\subsection{Die pre-Caesareaanse teks}

Die Caesareaanse teks lewer die meeste probleme van al die tekstipes en daar bestaan vandag geen konsensus dat daar enigsins so 'n tekstipe bestaan het nie. Waar die Alexandrynse en Westerse tekstipes reeds so lank terug as die 18de eeu geïdentifiseer is, is die Caesareaanse teks eers vroeg in die 20 ste eeu geïdentifiseer. Die geskiedenis van die teks is redelik duister en sentreer in hoofsaak om $\mathrm{P}^{45}$ en die teks van die kerkvader Origenes. Die ontstaan van hierdie teks is anvanklik in die 3 de eeu geplaas en aan Origenes se vertrek na Caesarea verbind. Daar word naamlik beweer dat Origenes ná sy vertrek na Caesarea uit 'n ander teks aanhaal as as die Alexandrynse teks, wat hy in Alexandrië gebruik het. Die teks wat hy in Caesarea gebruik het, kom in 'n groot mate ooreen met die teks wat in $\mathrm{P}^{45}$ voorkom. Vandag word anders gedink en word die ontstaan daarvan in Egipte gesoek. Daar word beweer dat Origenes hierdie teks reeds in Egipte gebruik het en dit met hom na Caesarea saamgeneem het.

Hierdie teks vertoon trekke van die Westerse teks, maar bevat ook elemente van die Alexandrynse teks sowel as eiesoortige lesings. Die probleem van hierdie teks lê daarin dat dit nie seker is of dit 'n afsonderlike tekstipe verteenwoordig nie. Sommiges meen dat die manuskripte wat as Caesareaans bestempel word, 'n blote vroeë vermenging van die Alexandrynse en Westerse tekste verteenwoordig, waarin ook nog elemente van die tekstradisies van die vroeë periode wat nie in die Alexandrynse en Westerse tekste neerslag gevind het nie, oorgebly het. 'n Samehangende probleem, wat blyk die tweede moontlikheid te versterk, is dat daar nog nie oortuigend in geslaag is om hierdie tekstipe buite die Evangelies en veral buite die Markusevangelie te identifiseer nie, hoofsaaklik omdat die manuskripte wat die teks bevat, met enkele uitsonderings, tot die Evangelies beperk is. Om hierdie probleme die hoof te bied en terselfdertyd aan die bestaan van die kenmerkende eienskappe van hierdie teks reg te laat geskied, is die Caesareaanse teks al beskryf as 'n tekstuele proses tussen die Alexandrynse en Westerse tekste (moontlik 'n vroeë spontane poging om die teks te standaardiseer?).

Die probleme rondom die bestaan en karakterisering van hierdie teks het daartoe gelei dat onderskei word tussen die Vroeë Caesareaanse teks en die Caesareaanse teks. Die eerste subteks word in werklikheid die Pre-Caesareaanse teks genoem en is 'n goeie illustrasie van die dilemma rondom hierdie teks. Dit verwys naamlik na 'n groep manuskripte waarin sekere eienskappe van die Caesareaanse teks voorkom en wat hulle dus van ander tekstipes onderskei, maar wat te min van hierdie eienskappe bevat om as 'n selfstandige tekstipe geklassifiseer te word. PreCaesareaans is dus 'n soort anachronistiese term om die aanloop of vroegste ontwikkeling van die tekstipe te tipeer en om die bronne van daardie vroegste 
ontwikkeling te karakteriseer en terselfdertyd aan te toon dat hulle nie werklik ten volle deel van die tekstipe as sodanig is nie. Die Pre-Caesareaanse teks verteenwoordig daarom die beweging tussen die Alexandrynse teks, die Westerse teks en die sekere elemente van die tradisies van die vroeë periode, wat uiteindelik op die Caesareaanse teks self uitgeloop het.

Wat is die eienskappe van hierdie tekstipe? Die belangrikste eienskap is die besondere soort vermenging van Alexandrynse en Westerse lesings, waarin gepoog word om 'n soort kompromie tussen die twee tekstipes daar te stel. Daarbenewens is daar 'n neiging tot afronding - veral stilistiese afronding - en 'n harmoniërende element in die teks te bespeur. Die eienskappe van hierdie tekstipe kan dus saamgevat word as 'n strewe na tekstuele, inhoudelike en stilistiese afgerondheid.

Literatuur: K Aland 1970/71; Carder 1969/70; Colwell 1969i; Fee 1971b; 1974a; Geerlings 1959; 1961a; 1961b; 1962a; Glasson 1966; Globe 1982; Hills 1947; 1949; Hurtado 1981b; Huston 1955; KW Kim 1949; Klijn 1959a; Lake, Blake \& New 1928; Lake \& Lake 1941; Metzger 1945; 1963d; 1966/67b; 1968b; 1971; Schäfer 1960; Souter 1960; Streeter 1924; Vaganey 1937; Wallace-Hadrill 1956; Zuntz 1953.

\section{DIE STANDAARDISERING VAN DIE TEKS (4DE EN 5DE EEU)}

Die 4de en vroeë 5de eeu kan as 'n tydperk van teksstandaardisering beskou word. Nie alleen het die Griekse standaardteks in hierdie tydperk sy beslag gekry nie, maar ook die Latynse en Siriese vertalings het hul standaarduitgawes, die Vulgata en die Peshitta, in hierdie tydperk gekry. Die belangrikste van hierdie gebeure vir die geskiedenis van die oorlewering van die Griekse Nuwe Testament was egter die standaardisering van die Griekse teks.

\subsection{Die Bisantynse standaardteks}

Oor die standaardiseringsproses self is daar min bekend. Anders as met die Latynse teks bestaan daar geen verwysing in kerklike geskrifte na so 'n ontwikkeling in die Griekse tekstradisie nie, iets wat sommige mense laat twyfel of daar werklik'n standaardisering plaasgevind het. Wanneer die bronne egter ontleed word, is dit duidelik dat iets in die 4de eeu moes gebeur het, want sedert hierdie tydperk kom 'n tekstipe voor wat nie in ouer bronne gevind word nie, en wat sy merk uiteindelik ook op latere getuienisse van ander tekstipes gelaat het. Die nuwe tekstipe is vir die eerste keer in die aanhalings van die kerkvader Johannes Chrysostomos sigbaar en sedert die 5de eeu kom dit in die oorgrote meerderheid manuskripte van die Griekse Nuwe Testament voor, nie soseer in die 5de eeu self as in die 6de en latere 
eeue nie. Hierdie teks het uiteindelik met verskillende name bekend geraak. Die mees algemene naam wat vandag gebruik word is die Bisantynse teks, maar dit word soms ook die Siriese teks, Koineteks, Meerderheidsteks of Kerklike teks genoem.

Presies hoe die standaardisering plaasgevind het, is nie duidelik nie. Daar is verskillende teorieë daaroor. Vroeër in die 20ste eeu is geglo dat die teks ontstaan het as gevolg van 'n hersiening deur Lucianus van Antiochië, wat 'n kerklike opdrag daartoe gekry het. Die feit dat hierdie teorie verklaar waarom die standaardteks die spoedige aanvaarding gekry het wat dit inderdaad te beurt geval het, tel in sy guns, want so spoedig as 'n eeu of twee later het dit die teksoorlewering geheel en al oorheers. Die feit dat daar geen dokumentasie van so 'n opdrag of kerklike besluit is nie, tel egter teen hierdie teorie. Ander beweer weer dat hierdie teks spontaan ontstaan het deur 'n reeks spontane resensies. Dit sou inderdaad die swygsaamheid van die kerklike literatuur daaroor kon verklaar, maar dan bly die vraag weer hoe sulke spontane resensies daarin geslaag het om die teksgeskiedenis so spoedig te domineer.

Waarskynlik lê die antwoord êrens tussen bogenoemde twee teorieë. Wanneer in gedagte gehou word dat daar uitgebreide tekskritiese arbeid en standaardiseringspogings van verskillende Bybeltekste in hierdie tydperk plaasgevind het, is dit ondenkbaar dat die Griekse teks, wat op hierdie stadium in definieerbare tekstipes oorgelewer is, nie aan hierdie proses onderwerp sou wees nie. Daar is verskeie voorbeelde van 'n tekskritiese bewussyn in hierdie tydperk: In die 3de eeu reeds bemoei Origenes hom met die teks van die Ou Testament deur sy uitgawe van die Hexapla - 'n majestueuse uitgawe van die Ou Testament wat ses tekste, onder andere drie Griekse vertalings, die Septuaginta en die vertalings van Theodotion en Aquilla, bevat het. Origenes toon ook in sy kommentare 'n belangstelling in die teks van die Griekse Nuwe Testament deurdat hy soms notas oor variante lesings by sy kommentare insluit. Buiten Origenes se werk aan die teks van die Septuaginta vir sy Hexapla, is dit bekend dat ook Hesychius van Egipte en Lucianus van Antiochië hulle met die teks van die Septuaginta besig gehou het. Beide hierdie kerkvaders was al daarvan verdink dat hulle ook by hersieningswerk aan die Griekse teks van die Nuwe Testament betrokke was. Daar is reeds verwys na die Vulgata, die resultaat van Hieronymus se standaardisering van die Latynse Nuwe Testament, en die Peshitta, die resultaat van waarskynlik Rabulla van Edessa se standaardisering van die oud-Siriese vertaling. Dit is bekend dat dit juis die talrykheid van die verskille in die manuskripte van die oud-Latynse teks was, wat die werk van Hieronymus geïnisieer het. Dieselfde geld waarskynlik van die Peshitta. Soos Origenes, toon ook Hieronymus sy belangstelling in die teks van die Nuwe Testament deur in sy kommentare soms aanmerkings oor tekskritiese probleme te maak. 
Dit is uit hierdie feite duidelik dat daar' $n$ klimaat van standaardisering in die 4 de en 5 de eeu bestaan het en dat daar in daardie tyd waarskynlik meer belangstelling in die teks van die Nuwe Testament bestaan het as op enige ander stadium in die eerste 16 eeue waarin die teks oorgelewer is. Dit is dus onwaarskynlik dat daar geen hersiening van die grondteks sou wees te midde van so baie hersienings van die vertalings nie. Die feit dat die Peshitta se tekstipe uiteindelik verskil van die tekstipe van sy voorgangers, die oud-Siriese teks, en met die Griekse standaardteks ooreenstem, suggereer dat so 'n hersiening inderdaad plaasgevind het, dat dit plaasgevind het voordat die Peshitta sy beslag gekry het en dat dit uiteindelik 'n direkte invloed op die Peshitta en die Siriese hersiening gehad het. Moontlik kan die swygsaamheid van die kerklike dokumente op dieselfde wyse verklaar word as hulle swygsaamheid ten opsigte van die vertalings van die Nuwe Testament. Hoewel geen rekord van die oud-Latynse, oud-Siriese of Koptiese vertalings in die kerklike geskrifte voorkom nie, is dit wel gemaak. Dit bewys die feit dat hulle bestaan. Op dieselfde wyse bewys die aard van die Bisantynse teks, sowel as die feit dat dit eers sedert die 4de eeu voorkom, dat so 'n hersiening moes plaasgevind het. Waar, wanneer, deur wie en op wie se gesag dit gedoen is, is egter onmoontlik om te sê. Moontlik is dit die voltooiing van die proses wat in die preCaesareaanse teks begin is, alhoewel die uiteindelike produk baie anders as die Caesareaanse teks gelyk het. Benewens die aanhalings van Johannes Chrysostomos, is die tekste van Kodeks A in die Evangelies en Kodeks W in Lk 8: 13-24: 53 die vroegste manuskripte wat aan hierdie tekstipe behoort.

Om saam te vat: Alles dui daarop dat daar in die 4de eeu 'n standaardisering van die Griekse teks plaasgevind het en dat die gevolge van hierdie standaardisering ' $n$ basies uniforme oorlewering van die Griekse teks in die Middeleeue meegebring het, wat ander tekstipes verdring het. Hoewel daar veral vroeg in die oorleweringsgeskiedenis van die standaardteks laat in die 5de eeu en selfs later, 'n aantal subtekstipes bestaan het, was die verskille tussen hierdie subtekstipes nie van so 'n aard dat dit in enige mate op die bestaan van afsonderlike tekstipes gedui het nie. Hierdie teks was selfs in sy vroegste vorm 'n basies uniforme teks en die nonBisantynse lesings in die subtekstipes is waarskynlik toe te skryf aan 'n vroeë periode van vermenging van tekstipes, deurdat lesings van die ander tekstipes nog in die manuskripte van die standaardteks ingekom het.

Literatuur: B Aland 1976; K Aland 1965; Aland \& Aland 1982; Birdsall 1970; Casey 1957; Champlin 1964; 1966; Colwell 1969; Jellicoe 1963; Kenyon 1912; S Lake 1937; Metzger 1961/62b; 1963c; Reicke 1966; Sturz 1984; Vaganey 1937; Westcott \& Hort 1974; Zuntz 1953. 


\subsection{Die Egiptiese of laat-Alexandrynse teks}

Ook die Alexandrynse teks het die redaksionele en hersieningspraktyke in hierdie tydperk nie gespaar gebly nie en daar is spore van redaksionele werk in die latere bronne van hierdie teks te vind. Reeds in die vroegste vorme van hierdie teks is daar tekens dat die teks deur veral Westerse lesings beïnvloed is. Selfs in 'n manuskrip soos Kodeks $\mathrm{X}$, wat vir' $\mathrm{n}$ lang tyd as een van die twee belangrikste manuskripte van die Alexandrynse tekstipe beskou is, word die invloed van die Westerse teks duidelik gesien. In die 4de eeu, dalk selfs laat in die 3de eeu, is daar egter tekens van 'n matige redaksionele versorging van die Alexandrynse teks. Sedert die 4de en 5 de eeu is daar nie alleen spore van Westerse lesings in verteenwoordigers van hierdie teks sigbaar nie, maar ook Caesareaanse lesings en veral lesings van die Bisantynse standaardteks. Die Bohairiese vertaling, en ook latere manuskripte soos Kodekse $\mathrm{C}$ en $\mathrm{L}$, is goeie voorbeelde hiervan. Om hierdie rede word daar tussen die proto-Alexandrynse of vroeë Alexandrynse teks (die Alexandrynse teks van die $2 \mathrm{de}$ en 3de eeu) en die Egiptiese of later-Alexandrynse teks (die Alexandrynse teks van die 4 de en 5de eeu) onderskei. In werklikheid is die Alexandrynse teks en Egiptiese teks dus niks meer as twee subtekstipes van dieselfde teksfamilie, wat chronologies op mekaar volg, nie.

Die Egiptiese tekstipe vertoon, vanweë die direkte verwantskap aan die Alexandrynse teks, in breë trekke dieselfde eienskappe as die Alexandrynse tekstipe, met die uitsondering dat die getuienisse van hierdie subtekstipe duidelike invloede van veral die Westerse en later ook Bisantynse teks vertoon.

Litcratuur: Kyk by Alexandrynse teks (4.1) hierbo.

\subsection{Die Caesareaanse teks}

In hierdie tydperk bereik die proses wat as die pre-Caesareaanse teks bekend gestaan het ook voltooiing. Soos die Egiptiese teks vertoon ook hierdie tekstipe nie veel ander eienskappe as die vroeë proses waaruit dit ontstaan het nie, behalwe dat ook hierdie teks groter tekens van vermenging en ook afronding vertoon, deurdat die invloed van ander teksfamilies in 'n groter mate as voorheen in die getuienisse van hierdie tekstipe sigbaar word. Om die Caesareaanse tekstipe van die vroeë ontwikkeling te onderskei, word daar soms van hierdie teks as die laat-Caesareaanse teks gepraat.

Literatuur: Kyk by pre-Caesareaanse teks (4.3) hierbo. 


\subsection{Die (laat-)Westerse Teks}

Ook die Westerse teks het nie aan die hersieningsarbeid van hierdie tydperk ontkom nie. Hoewel die hersiening in hoofsaak tot die standaardisering van die Latynse manuskripte en die produksie van die Vulgata beperk was, is daar duidelike tekens van doelbewuste redaksionele arbeid ook in die Griekse teks van Kodeks D te bespeur. Hierdie manuskrip word vandag beskou as 'n swak weergawe van die Westerse teks en moontlik as 'n verteenwoordiger van die finale fase van herhaalde redaksionele arbeid in die Griekse Westerse teks. Dit is duidelik dat D op taalkundige en inhoudelike vlak aan ernstige redaksionele versorging blootgestel was. Die belangrikste gevolg hiervan is die duidelike anti-Judaïstiese element in veral die teks van Handelinge in hierdie manuskrip. Wanneer die hersienings in die Griekse tradisie van hierdie tekstipe plaasgevind het, is moeilik om te sê. Waarskynlik het dit oor 'n lang tydperk herhaaldelik plaasgevind. Dit word duidelik as in ag geneem word dat sommige manuskripte sekere trekke van die D-teks vertoon en dus aan $\mathrm{D}$ verwant is, hoewel hulle voor $\mathrm{D}$ gedateer word.

Literatuur: Kyk by Westerse teks (4.2) hierbo.

\section{DIE VROEë STANDAARDTEKS (5DE TOT 9DE EEU)}

Die eerste aantal eeue na die standaardisering van die teks, kan beskou word as die tydperk van die vestiging van die standaardteks. In hierdie tydperk kom daar soms nog subtekstipes in die Bisantynse teks voor waarin soms nog lesings van die ouer tekstipes gevind word. Dit is egter reeds in hierdie periode duidelik dat die Bisantynse teks die oorlewering van die Griekse teks van die Nuwe Testament domineer en dat alle ander tekstipes finaal uitgesterf het. Slegs in enkele gevalle kom daar uit hierdie tydperk nog manuskripte voor wat aan 'n ander tekstipe as die standaardteks behoort. Dit gebeur veral vroeg in die tydperk en vertalings soos die Armeense en Georgiese, wat aan die Caesareaanse teks verwant is, is bekende voorbeelde. Sulke manuskripte moet daaraan toegeskryf word dat dit 'n tyd vir die standaardteks geneem het om sy invloed oral te versprei en dat die reste van ander tekstipes nog in sekere dele voorgekom het voordat die standaardteks ook daar begin domineer het. Dit is waarskynlik in 'n sekere sin ook die bronne vir enkele indiwiduele manuskripte later in hierdie tydperk wat aan ander tekstipes behoort. Sulke manuskripte is weinig meer as toevallige verskynsels en is waarskynlik daaraan te wyte dat vroeë manuskripte wat in kloosters se biblioteke was en die standaardisering van die teks voorafgegaan het, in die kopieerproses toevallig as archetipes gebruik is. Daar was geen sistematiese poging om enige ander tekstipe te 
bewaar of voort te sit nie en na die vroeë Middeleeue was die proses van die standaardisering van die teks en die popularisering van die Bisantynse standaardteks finaal voltooi.

Waarom het dit gebeur? Waarom het ander tekstipes uiteindelik uitgesterf en hoe was dit moontlik dat 'n tekstipe wat in die 4de eeu ontstaan het, uiteindelik alle ander tekstipes verdring en die teksgeskiedenis gedomineer het? Dit is een van die belangrikste vrae om te beantwoord en word dikwels onder mense, wat meen dat die standaardteks in der waarheid die oudste teksfamilie en 'n getroue weergawe van die teks van die oorspronklike Nuwe Testament is, gelug. Die vernaamste element van hierdie argument is dan dat dit onmoontlik is dat 'n teks wat 'n agterstand van vier eeue in die oorleweringsproses op ander tekstipes het, uiteindelik in soveel meer manuskripte oorgelewer kan wees as die ander ouer tekstipes (ongeveer neëntig tot vyf en neëntig persent van alle bekende manuskripte bevat die Bisantynse standaardteks). Hoe word hierdie probleem opgelos?

Die antwoord op hierdie vraag moet waarskynlik in die fisiese omstandighede waaronder die teks oorgelewer is, gesoek word. Dit moet in gedagte gehou word dat die oorlewering van die Griekse teks sedert die 3de of 4de eeu geografies al hoe meer beperk is. Sedert die vertaling van die Nuwe Testament in Latyn, en veral sedert die standaardisering van die Latynse teks en die ontstaan van die Vulgata in die 4de eeu, is die Nuwe Testament in die Weste uitsluitlik in Latyn oorgelewer. Die Westerse teks is dus nie meer in Grieks oorgelewer nie, maar in die Latynse Vulgata. Dit is duidelik uit die feit dat daar vandag baie meer manuskripte van die Vulgata as van die Griekse teks bekend is. Net so het die Koptiese tradisie aanvanklik die rol van die draer van die teks in Egipte oorgeneem voordat die Christendom as geheel gedurende die Middeleeue in Egipte uitgesterf het. Die enigste plek waar die Griekse teks in die Middeleeue oorgelewer is, is die Ooste, die plek waar die standaardisering van die teks plaasgevind het. Sedert ongeveer die $6 \mathrm{de}$ of $7 \mathrm{de}$ eeu is die teks dus uitsluitlik oorgelewer in die gebiede waar die standaardteks geproduseer is en, soos in die geval van die Latynse vertaling, is dit te wagte dat die gestandaardiseerde vorm van die teks, en nie 'n ander vorm nie, in hierdie gebied oorgelewer sou word. Die ander tradisies is dus deur fisiese oorsake afgesny en vanweë praktiese omstandighede nie meer oorgelewer nie. Die omstandighede het dus binne 'n eeu of twee na die ontstaan van die standaardteks ideaal vir hierdie teks geword om die dominerende teks te word. Die verbondenheid van hierdie teks aan die Ooste is ook die vernaamste rede waarom dit die Bisantynse teks genoem word. Dit was naamlik die teks wat in die Bisantynse tydperk en in die gebied van die Bisantynse ryk gedomineer het.

'n Interessante ontwikkeling wat in hierdie tydperk plaasgevind het en wat 
ongetwyfeld bygedra het tot die spoedige uitskakeling van subtekstipes en bygedra het tot die uniformiteit van hierdie tekstipe, was die ontwikkeling van 'n liturgiese teks deur die gebruik van leksionaria. Die oudste leksionarion wat vandag bekend is, dateer uit hierdie tydperk. Ofskoon dit uit die gebruik van leksionarionsimbooltjies in gewone manuskripte duidelik is dat die praktyk om die teks vir liturgiese doeleindes voor te berei waarskynlik ouer as hierdie tydperk was, kan met redelike sekerheid afgelei word dat dit eers in hierdie tydperk was dat manuskripte spesiaal vir hierdie doel gemaak is. Die uniformiteit van die leksionarionteks, 'n teks wat spesiaal vir liturgiese doeleindes geskep is en wat 'n getroue weergawe van die Bisantynse standaardteks was, het die bekendheid met die teks onder gebruikers verhoog, wat meegebring het dat skriptors hulle kopieë van die Griekse Nuwe Testament in al hoe groter mate by die bekende liturgiese teks aangepas het.

Hoe het hierdie standaardteks gelyk? Waarskynlik die mees betekenisvolle eienskap van hierdie teks is die feit dat daar 'n spesifieke neiging tot konflasie in die teks voorkom, en dit is op grond hiervan dat die bronne van die standaardteks geïdentifiseer kan word. Talle van die konflasies is samevoegings van tipiese lesings van die Westerse en Alexandrynse tekste. In baie ander gevalle stem die Bisantynse teks met of die Westerse of die Alexandrynse teks ooreen, wat daarop dui dat die redaktors van die teks in sulke gevalle nie die lesings saamgevoeg het nie, maar 'n keuse gemaak het en een van die twee gekies het. Hieruit kan afgelei word dat die Bisantynse teks 'n basies eklektiese teks is, wat saamgestel is uit 'n siftingsproses met manuskripte van die ouer tekstipes as bronne. In aansluiting hierby kom daar' $n$ duidelike tendens tot literêre en grammatikale afronding in die manuskripte van hierdie teks voor. Dit bestaan in besonder uit pogings om uitdrukkings te voltooi en af te rond deur die byvoeging van partikels, voegwoorde, voornaamwoorde, en so meer. Dit is dus 'n poging om die teks se betekenis meer eksplisiet te maak en so die inhoud daarvan makliker begrypbaar te maak. Verder word die teks ook gekenmerk deur 'n tendens tot harmoniëring van parallelle gedeeltes, veral in die Evangelies. 'n Aantal treffende interpolasies kom ook in die teks voor. Die teks is dus in meer as een opsig 'n lang teks, wanneer dit met ander tekstipes vergelyk word. Die aard van die lengte van die teks lê sowel in die konflasies, die interpolasies as die pogings tot afronding deur kort byvoegings. Soos die Westerse teks is daar ook ' $n$ teologiese kenmerk in hierdie teks. Anders as die Westerse teks het dit egter 'n duidelik ortodokse karakter.

Omdat die teks 'n saamgestelde teks is wat op 'n sistematiese bewerking van vroeëre tekstipes gebaseer is - omdat dit dus 'n gefabriseerde teks is - is dit uiteraard min werd vir die herstel van die oorspronklike teks van die Nuwe Testament en dit 
is gevolglik onwaarskynlik (ofskoon nie onmoontlik nie en in geïsoleerde gevalle tog waarskynlik) dat lesings wat uitsluitlik in die Bisantynse teks voorkom, lesings van die oorspronklike teks kan wees. Dit is egter seker dat die oorspronklike teks van die Griekse Nuwe Testament nie die tipiese eienskappe van die Bisantynse teks in geheel gehad het nie.

Literatuur: B Aland 1976; Birdsall 1970; Champlin 1966; Fee 1964; Kenyon 1933a; Kilpatrick 1965a; Metzger 1966; 1968b; 1971; Saunders 1952; Sturz 1984; Tarelli 1942a; Vaganey 1937; Westcott \& Hort 1974; Zuntz 1942a; 1942 b; 1953.

\section{DIE MIDDELEEUSE MINUSKELTEKS (9DE TOT 16DE EEU)}

\subsection{Die laat-Bisantynse teks}

Teen die 9de eeu, toe daar begin is om minuskelmanuskripte ook vir die oorlewering van die Nuwe Testament te gebruik, was die proses van standaardisering reeds afgehandel en het die Standaardteks die teksgeskiedenis reeds gedomineer. Die teks het in hierdie tydperk nog meer uniform geword - iets waarin die gebruik van minuskels waarskynlik 'n groot rol gespeel het, omdat dit, vanweë die feit dat verskillende simbole gebruik is, sekere soorte foute in die kopieerproses beperk het -, sodat die oorgrote meerderheid minuskels en leksionaria wat vandag bestaan, verteenwoordigers van die laat-Bisantynse standaardteks is. Die kenmerke van hierdie teks verskil weinig van dié van die vroeë standaardteks. Dit blyk egter dat die teks nog meer afgerond is as die vroeë standaardteks, sodat dit wat in die 4de eeu begin is, op spontane wyse voortgedra is en uiteindelik 'n teks gelewer het wat in vele opsigte 'n afgeronde teks was, inhoudelik, tekstueel en grammatikaal. Onder die verteenwoordigers van hierdie laat-Bisantynse tekstipe kom ook 'n aantal sub-tekstipes voor. Die verskille tussen hierdie subtekstipes is egter minimaal en die onderskeidende lesings daarvan is in baie gevalle beperk tot klein verskille in die gebruik van sekere voorsetsels of die byvoeging of weglating van 'n voornaamwoord - dus grammatikale en stilistiese detail. Inhoudelik is hierdie tekstipe egier so uniform dat inhoudelike variasie vir alle praktiese doeleindes geïgnoreer kan word. Dit is dus duidelik dat die proses van standaardisering, hoewel formeel waarskynlik reeds in die vroeë Middeleeue afgehandel, in die laat-Middeleeuse minuskelteks uiteindelik sy volle wasdom bereik het.

Met enkele uitsonderings behoort alle minuskelmanuskripte van die Griekse Nuwe Testament en alle leksionaria tot hierdie teks. Dit geld ook alle kerkvaders 
uit hierdie tydperk en al die laatste vertalings van die Griekse Nuwe Testament, kortliks dus, alle verteenwoordigers van die Griekse Nuwe Testament na die 9de eeu.

Literatuur: Champlin 1964; 1966; Colwell 1935; Geerlings 1962b; 1963; 1968a; 1968b; Richards 1977a; Wisse 1982; Wisse \& McReynolds 1970.

\subsection{Manuskripte van ander tekstipes}

Hoewel die Bisantynse teks die geskiedenis teen hierdie tyd volledig gedomineer het, is daar tog 'n aantal verrassende manuskripte uit hierdie tydperk wat aan 'n vroeë tekstipe verwant is. Veral in die Evangelies het enkele minuskels 'n Egiptiese teks en 'n aantal ander 'n (laat-)Caesareaanse teks. In die Openbaringboek tel een of twee minuskels wat 'n ou teks van Openbaring het onder die belangrikste bronne van die Openbaringboek wat bekend is, en word hulle gereken as selfs meer getroue verteenwoordigers as van die vroegste manuskripte wat die teks van Openbaring bevat.

Hoe moet hierdie verskynsel verklaar word? Die bestaan van hierdie manuskripte is bloot 'n aanduiding daarvan dat daar in sommige kloosters en kerksentra steeds vroeë manuskripte beskikbaar was wat 'n vroeë teks gehad het, en dat hierdie manuskripte soms in die kopieerproses as archetipes gebruik is. 'n Belangrike beginsel wat egter uit die bestaan van hierdie manuskripte afgelei kan word, is dat manuskripte wat baie laat gedateer word, soms belangriker kan wees as vroeëre manuskripte, omdat hulle 'n ouer tekstipe bevat.

\section{SAMEVATTING}

In die middel van die 15 de eeu het 'n gebeurtenis plaasgevind wat die hele Westerse beskawing sou verander. Gutenberg het die boekdrukkuns ontwikkel. Hierdie ontdekking het ook die oorlewering van die Griekse Nuwe Testament geraak. Dit het 'n abrupte einde gemaak aan die oorlewering van boeke deur middel van handgeskrewe kopieë. So eindig dus die, in vele opsigte aangrypende, verhaal van die geskrewe oorlewering van die Griekse Nuwe Testament vroeg in die 16de eeu. Terselfdertyd het egter 'n selfs meer aangrypende geskiedenis 'n aanvang geneem die geskiedenis van die gedrukte oorlewering van die Griekse Nuwe Testament.

Die geskiedenis van die geskrewe oorlewering van die teks kan grafies soos volg voorgestel word: 


\section{OORSPRONKLIKE TEKS}

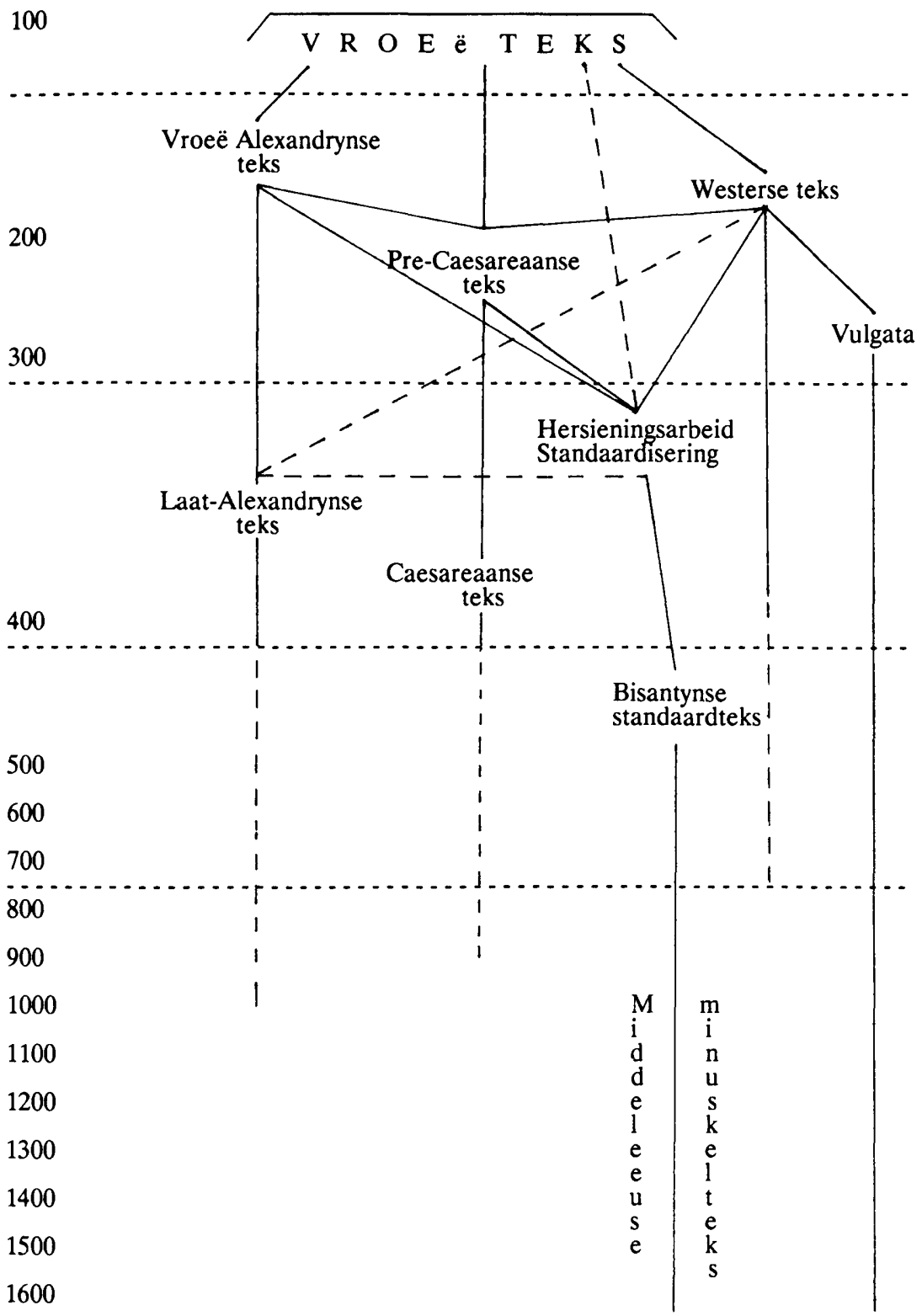

